\title{
ANALISIS LAPORAN KEUANGAN BERDASARKAN TINGKAT RENTABILITAS BANK PERKREDITAN RAKYAT (BPR) BATANG PALANGKI"
}

\author{
LASTRI OKTAVIA, JHON FERNOS \\ Akademi Keuangan dan Perbankan "Pembangunan" \\ Jhonfernos@akbpstie.ac.id
}

\begin{abstract}
In general, company efficiency decreased in 2014 and 2015. Management effectiveness from 2013 to 2014 and 2014 to 2015 declined significantly, especially at the NPM to below BI standards. The company's ability to generate net income from year to year has decreased, especially from 2014 to 2015 to below the BI standard. The productivity of company assets is very low, this is due to profit margins due to low asset turnover. The company's ability to generate profits from operating capital returns in 2013 was very efficient because the value of ROE in 2013 was above the BI standard.
\end{abstract}

Keywords : Financial Report, Ratio Rentabilitas, BPR

\section{PENDAHULUAN}

Pada era globalisasi saat ini peranan bank sangat penting bagi mayarakat Indonesia, karena pada dasarnya perbankan bertujuan untuk menunjang pembangunan nasional dalam meningkatkan kesejahteraan masyarakat. Dunia perbankan sendiri saat ini mengalami perkembangan yang pesat, Baik Bank Umum maupun Bank Perkreditan Rakyat, maka setiap bank diharapkan dapat menjaga Rentabilitas banknya.

Menurut Undang-undang RI Nomor 10 tahun 1998 tentang perubahan Undangundang Nomor 7 tahun 1992 Bank adalah Badan Usaha yang menghimpun dana dari masyarakat dalam bentuk simpanan dan menyalurkanya kepada masyarakat dalam bentuk kredit atau bentuk-bentuk lainnya dalam rangka meningkatkan taraf hidup rakyat banyak.

Dalam undang-undang Nomor 10 tahun 1998 tentang perbankan, menurut jenisnya bank terdiri dari Bank Umum dan Bank Perkreditan Rakyat(BPR). Bank Perkreditan Rakyat(BPR) adalah bank yang melaksanakan kegiatan usaha secara konvensional atau berdasarkan prinsip syariah yang dalam kegiatannya tidak memberikan jasa lalu lintas pembayaran. Salah satu BPR di Indonesia adalah Bank Perkreditan Rakyat Batang Palangki.

BPR telah tumbuh dan berkembang sebagai lembaga kecil di masyarakat yang merupakan ujung tombak dalam memacu pertumbuhan ekonomi khususnya usaha kecil. Kondisi ini wajar karena BPR memang lahir dari masyarakat bawah, sehingga BPR tetap menyatu dengan masyarakat. Keberadaan BPR di Indonesia mampu menunjukan perannya memberikan jasa pelayanan kepada usaha kecil.

Agar dapat melaksanakan tugas pokok dan mempertahankan kelangsungan BPR kepercayaan masyarakat sangat penting. Untuk memperoleh gambaran tentang perkembangan finansial dari bank bersangkutan, dimana data finansial itu tercemin didalam laporan keuangan. 
Laporan keuangan merupakan data-data keuangan yang sifatnya kuantitatif, dan berisikan sumber informasi yang penting untuk mngetahui dan menganalisis keadaan keuangan suatu bank. Menurut Myer dalam bukunya Financial Statement Analisis mengatakan bahwa yang dimaksud dengan laporan keuangan adalah: Dua daftar yang disusun oleh Akuntan pada akhir periode untuk suatu perusahaan. Kedua daftar itu adalah daftar neraca atau daftar posisi keuangan dan daftar pendapatan atau daftar laba rugi. Pada waktu akhir-akhir ini sudah menjadi kebiasaaan bagi perseroanperseroan untuk menambahkan daftar ketiga yaitu daftar surplus atau daftar laba yang dibagikan (laba yang ditahan).

Dalam menganalisa dan menilai posisi keuangan suatu perusahaan mempunyai tujuan akhir yang ingin dicapai oleh suatu perusahaan yang terpenting adalah memperoleh laba atau keuntungan yang maksimal oleh karena itu, manajemen perusahaan dalam pratiknya dituntut harus mampu untuk memenuhi target yang telah ditetapkan artinya besar keuntungan haruslah dicapai sesuai dengan yang diharapkan dan bukan berarti asal untung. Untuk mengukur tingkat keuntungan suatu perusahaan, digunakan rasio keuntungan yang dikenal dengan nama Rasio Rentabilitas.

Menurut Munawir (2007 : 33) menyebutkan bahwa Rentabilitas adalah menunjukkan kemampuan perusahaan untuk menghasilkan laba selama periode tertentu. Rentabilitas suatu perusahaan diukur dengan kesuksesan perusahaan dan kemampuan menggunakan aktivanya secara produktif, dengan demikian rentabilitas suatu perusahaan dapat diketahui dengan memperbandingkan antara laba yang diperoleh dalam suatu periode dengan jumlah aktiva atau jumlah modal perusahaan tersebut.

Berdasarkan pernyataan tersebut suatu bank dapat mengukur atau menganalisa laporan keuangan berdasarkan tingkat Rentabilitas yang sesuai dengan rasio keuntungan yaitu:

Rentabilitas suatu perusahaan diukur dengan kesuksesan perusahaan dan tersebut. Masalah rentabilitas adalah berhubungan untuk mengukur suatu efiiensi penggunaan modal dalam suatu perusahaan dengan memperbandingkan antara laba dengan modal yang digunakan dalam operasi, oleh karena itu keuntungan yang besar tidak menjamin atau bukan merupakan ukuran bahwa perusahaan tersebut Rendabel. Oleh karena itu bagi manajemen atau pihak-pihak lain, rentabilitas yang tinggi lebih penting dari pada keuntungan yang besar.

Suatu perusahaab yang rendabel, maka perusahaan tersebut pada umumnya akan dapat beroperasi secara stabil pula.

Tabel 1.1

Perkembangan Rasio Rentabilitas

PT. BPR Batang Palangki

Tahun 2013-2015

\begin{tabular}{cccc}
\hline Tahun & Net Profit Margin & Return on Aset & Return on Equity \\
\hline 2013 & $2,618 \%$ & $6,17 \%$ & $27,55 \%$ \\
2014 & $2,422 \%$ & $4,23 \%$ & $24,3 \%$ \\
2015 & $2,135 \%$ & $3,48 \%$ & $25,11 \%$
\end{tabular}

Sumber: BPR Batang Palangki, Data diolah. 
Dari data diatas menunjukan bahwa pada tahun 2013 NPM PT.BPR Batang Palangki 2,618\%, tahun 2014 2,422\% dan tahun 2015 2,135\% yang diperoleh dari laba bersih setelah pajak dibagi dengan pendapatan operasional, sedangkan untuk ROA tahun $20136,17 \%$, tahun 2014 4,23\%, tahun 2015 3,48\% yang diperoleh dari laba bersih setelah pajak dibagi total aset, dan untuk ROE tahun 2013 27,55\%, tahun 2014 $24,3 \%$, tahun $201525,11 \%$ yang diperoleh dari laba bersih setelah pajak dibagi dengan modal sendiri.

Dari uraian diatas, penulis tertarik untuk mengetahui bagaimana kemampuan PT.BPR Batang Palangki dalam menggunakan modalnya secara efisien serta menggunakan aktivanya secara produktif untuk menghasilkan laba selama periode tertentu dengan tujuan perusahaan tersebut dapat mengoperasikan secara stabil dan mampu mengembalikan semua hutang-hutangnya kepada pihak lain. Oleh karena itu penulis tertarik untuk menganalisis laporan keuangan PT.BPR Batang Palangki untuk mengetahui tingkat Rentabilitas bank tersebut baik dari tahun sebelumnya ataupun tahun yang akan datang, maka dari itu penulis memilih judul "Analisis Laporan Keuangan Berdasarkan Tingkat Rentabilitas Bank Perkreditan Rakyat (BPR) Batang Palangki”

Adapun perumusan masalah dalam penulisan tugas akhir ini yaitu Bagaimana tingkat Rentabilitas pada BPR Batang Palangki.

\section{LANDASAN TEORI}

Bank merupakan salah satu lembaga keuangan yang mempunyai peranan penting didalam perekonomian suatu Negara sebagai lembaga perantara keuangan. Bank dalam pasal 1 ayat (2) UU No. 10 Tahun 1998 tentang perubahan UU No. 7 Tahun 1992 tentang perbankan adalah badan usaha yang menghimpun dana dari masyarakat dalam bentuk simpanan dan menyalurkanya kepada masyarakat dalam bentuk kredit dan bentuk-bentuk lain dalam ranka meningkatkan taraf hidup rakyat banyak.

Bank-bank disebuah Negara bisa dibedakan menjadi beberapa jenis yaitu:

1. Bank Sentral

Bank dengan tugas mengeluarkan uang kertas serta uang logam untuk alat pembayaran sah disebuah Negara. Tugas lainnya adalah menjaga konversi uang tadi terhadap nilai emas dan perak.

2. Bank Umum

Institusi keuangan yang berwenang memberikan pinjaman atau melakukan investasi dari dana tabungan yang berhasil dihimpunnya, namun juga bisa memberikan pinjaman dengan mengeluarkan sendiri yang dinamakan uang giral.

3. Bank Perkreditan Rakyat

Bank yang menjalankan usahanya secara tradisional atau bisa juga dengan mendasarkannya pada kaidah islam dimana aktivitasnya tak menyediakan jasa pada lalu lintas pembayaran.

\section{Pengertian Bank Konvensional}

Menurut Undang-undang Nomor 10 tahun 1998 Bank Konvensional adalah Bank yang melaksanakan kegiatan usaha secara konvensionalyang dalam kegiatannya memberikan jasa dalam lalu lintas pembayaran.

Pada bank konvensional, kepentingan pemilik dana (deposan) adalah memperoleh imbalan berupa bunga simpanan yang tinggi,sedang kepentingan pemegang saham adalah diantaranya memperoleh spread yang optimal antara suku bunga simpanan dan suku bunga pinjaman (mengoptimalkan interest difference). Dilain 
pihak kepentingan pemakai dana (debitur) adalah memperoleh tingkat bunga yang rendah (biaya murah). Dengan demikian terhadap ketiga kepentingan dari tiga pihak tersebut terjadi antagonisme yang sulit diharmoniskan. Dalam hal ini bank konvensional berfungsi sebagai lembaga perantara saja.

\section{Analisis Laporan Keuangan}

Setelah laporan keuangan disusun berdasarkan data yang relevan, serta dilakukan dengan prosedur akuntansi dan penilaian yang benar, akan terlihat kondisi keuangan perusahaan yang sesungguhnya. Kondisi keuangan yang dimaksud adalah diketahuinya berapa jumlah harta, kewajiban, serta modal dalam neraca yang dimiliki. Kemudian, juga akan diketahui jumlah pendapatan yang diterima dan jumlah biaya yang dikeluarkan selama periode tertentu. Dengan demikian, dapat diketahui bagaimana hasil usaha (laba atau rugi) yang diperoleh selama periode tertentu dari laporan laba rugi yang disajikan.

Agar laporan keuangan menjadi lebih berarti sehingga dapat dipahami dan dimengerti oleh berbagai pihak, perlu dilakukan analisis laporan keuangan. Bagi pihak pemilik dan manajemen, tujuan utama analisis laporan keuangan adalah agar dapat mengetahui posisi keuangan perusahaan. Dengan mengetahui posisi keuangan, setelah dilakukan analisis laporan keuangan secara mendalam, akan terlihat apakah perusahaan dapat mencapai target yang telah direncanakan sebelumnya.

Hasil analisis laporan keuangan juga akan memberikan informasi tentang kelemahan dan kekuatan yang dimiliki perusahaan. Dengan mengetahui kelemahan ini, manajemen akan dapat memperbaiki atau menutupi kelemahan tersebut. Kemudian kekuatan yang dimiliki perusahaan harus dipertahankan atau ditingkatkan. Kekuatan ini dapat dijadikan modal selanjutnya kedepan. Dengan adanya kelemahan dan kekuatan yang dimiliki akan tergambar kinerja manajemen selama ini.

Pada akhirnya bagi pihak pemilik dan manajemen, dengan mengetahui posisi keuangan dapat merencanakan dan mengambil keputusan yang tepat tentang apa yang harus dilakukan kedepan. Perencanaan kedepan dengan cara menutupi kelemahan yang ada, mempertahankan posisi yang ada sesuai dengan yang diinginkan dan berupaya untuk meningkatkan lagi kekuatan yang sudah diperolehnya selama ini.

Analisis laporan keuangan perlu dillakukan secara cermat dengan menggunakan metode dan teknik analisis yang tepat sehingga hasil yang diharapkan benar-benar tepat pula. Kesalahan dalam memasukan angka atau rumus akan berakibat pada tidak akuratnya hasil yang hendak dicapai. Kemudian hasil perhitungan tersebut, dianalisis dan diinterpretasikan sehingga diketahui posisi keuangan yang sesungguhnya. Kesemuanya ini harus dilakukan secara teliti, mendalam, dan jujur.

\section{Ratio Keuangan}

Laporan keuangan merupakan media informasi yang digunakan oleh perusahaan yang bersangkutan untuk melaporkan keadaan dan posisi keuangannya kepada pihak-pihak yang berkepentingan, terutama pada pihak kreditor, investor dan pihak-pihak manajemen dari perusahaan itu sendiri.

Rasio finansial atau Rasio keuangan merupakan alat analisis keuangan perusahaan untuk menilai kinerja suatu perusahaan berdasarkan perbandingan data keuangan yang terdapat pada pos laporan keuangan (neraca, laporan laba/rugi, laporan aliran kas). Rasio menggambarkan suatu hubungan atau perimbangan (mathematical relationship) antara suatu jumlah tertentu dengan jumlah yang lain. Rasio-rasio keuangan dikelompokan kedalam lima kelompok dasar, yaitu:

\section{Rasio Likuiditas}


Rasio likuiditas digunakan untuk mengukur kemampuan perusahaan dalam menyelesaikan kewajiban jangka pendeknya.

2. Rasio Leverage (hutang)

Rasio hutang digunakan untuk mengukur seberapa besar operasi perusahaan dibiayai dari hutang.

3. Rasio Aktivitas

Yaitu rasio yang digunakan untuk mengukur efektivitas operasi perusahaan dalam memanfaatkan sumber-sumber dana yang ada.

4. Rasio Rentabilitas

Rentabilitas rasio sering disebut profitabilitas usaha.rasio ini digunakan untuk mengukur tingkat efisiensi usaha yang di capai oleh suatu perusahaan.dan mengukur efektifitas operasi perusahaan dlam menghasilkan laba.

5. Rasio Penilaian

Yaitu nisbah untuk mengukur kemampuan manajemen untuk menciptakan nilai perusahaan.

6. Rasio Pertumbuhan

Merupakan rasio yang menggambarkan kemampuan perusahaan mempertahankan posisi ekonominya ditengah pertumbuhan perekonomian dan sektor usahanya.

\section{Jenis dan Sumber Alat Rentabilitas}

1. Net Profit Margin

Rasio ini merupakan rasio yang digunakan untuk mengukur kemampuan bank dalam menghasilkan net income dari kegiatan operasi pokoknya. Atau Merupakan kemampuan perusahaan dalam menghasilkan keuntungan dibandingkan dengan penjualan yang dicapai.. Rumus untuk mencari Net Profit Margin sebagai berikut:

$$
\text { Net Profit Margin }=\frac{\text { Laba Bersih Setelah Pajak }}{\text { Pendapatan Operasional }} \times 100 \%
$$

2. Return on Asset (ROA)

Return on Asset digunakan untuk mengukur kemampuan manajemen dalam memperoleh profitabilitas dan manajerial efisiensi secara overall. Atau Sering disebut sebagai rentabilitas ekonomis yaitu merupakan kemampuan perusahaan dalam menghasilkan laba dengan semua aktiva yang dimiliki oleh perusahaan.Rumus untuk mencari Return on Asset sebagai berikut:

$$
\text { Return on Asset }=\frac{\text { Laba Bersih Setelah Pajak }}{\text { Total Asset }} \times 100 \%
$$

3. Return on Equity (ROE)

Merupakan rasio yang digunakan untuk mengukur kemampuan manajemen bank dalam mengelola capital yang ada untuk mendapatkan net income. Dan Sering disebut dengan rentabilitas modal sendiri yaitu merupakan kemampuan perushaan dalam menghasilkan keuntungan dengan modal sendiri yang dimiliki. Rumus untuk mencari Return on Equity sebagai berikut:

$$
\text { Return on Equity }=\frac{\text { Laba Bersih Setelah Pajak }}{\text { Modal Sendiri }} \times 100 \%
$$




\section{METODE PENELITIAN}

Dalam pengumpulan data dan bahan untuk penelitian ini digunakan metode penelitian sebagai berikut:

1. Metode Pengumpulan Data

a. Study lapangan (field reseach)

Peninjauan langsung ke objek penelitian yang dipilih untuk meneliti hasil data primer. Penelitian langsung kelapangan ini akan dapat membantu penulis untuk melengkapi data yang diperlukan. Adapun cara riset lapangan ini adalah dengan mewawancarai langsung pihak-pihak yang berkepentingan dalam hal ini adalah perusahaan dan instansi yang terkait.

b. Study perpustakaan (library perpustakaan)

Penelitian ini dilakukan ke perpustakaan berupa buku-buku ilmiah dan tulisantulisan yang berhubungan dengan pembahasan yang dilakuakan.

2. Metode Analisa Data

Dalam menganalisa data, menggunakan analisa kualitatif dan kuantitatif. Dimana metode kualitatif menggambarkan, memahami dan menjelaskan data yang diteliti selama penelitian berlangsung, sedangkan metode kuantitatif menganalisa perhitungan tingkat Rentabilitas pada BPR Batang Palangki. Penulis menggunakan analisis data kuantitatif sebagai metode penelitian yang menjelaskan secara deskriptif mengenai perbandingan Rasio Rentabilitas pada PT. BPR Batang Palangki Sijunjung.

\section{HASIL DAN PEMBAHASAN}

Tabel 3.1

Perkembangan Net Profit Margin

PT. BPR Batang Palangki Sijunjung

Tahun 2013-2015

\begin{tabular}{cccccrr}
\hline Keterangan & \multicolumn{2}{c}{$\mathbf{2 0 1 3}$} & \multicolumn{2}{c}{$\mathbf{2 0 1 4}$} & \multicolumn{2}{c}{$\mathbf{2 0 1 5}$} \\
\hline Pendapatan Operasional & Rp & 2.104 .492 & Rp 2.009 .656 & Rp & 2.359 .768 \\
Laba Bersih Setelah Pajak & Rp & 551.083 & Rp & 486.779 & Rp & 503.999 \\
\hline
\end{tabular}

Sumber: BPR Batang Palangki, Data diolah

1. Net Profit Margin

a. Tahun 2013

$$
\begin{gathered}
\mathrm{NPM}=\frac{\text { Laba Bersih Setelah Pajak }}{\text { Pendapatan Operasional }} \times 100 \% \\
=\frac{R p 551.083}{R p 2.104 .492} \times 100 \% \\
=2,618 \%
\end{gathered}
$$

Angka diatas memberikan arti bahwa setiap Rp 1 nilai penjualan, 2,618\% diantaranya (atau Rp 0,02618) akan menghasilkan laba setelah pajak. Perlu dipahami bahwa rasio ini merefleksikan: harga pokok penjualan, beban-beban operasi, beban keuangan(beban bunga) dan pajak. 
b. Tahun 2014

$$
\begin{gathered}
\text { NPM }=\frac{\text { Laba Bersih Setelah Pajak }}{\text { Pendapatan OPerasional }} \times 100 \% \\
=\frac{R p 486.779}{R p 2.009 .656} \times 100 \% \\
=2,422 \% 1
\end{gathered}
$$

Angka diatas memberikan arti bahwa setiap Rp 1 nilai penjualan, 2,422\% diantaranya (atau Rp 0,02422) akan menghasilkan laba setelah pajak. Perlu dipahami bahwa rasio ini merefleksikan: harga pokok penjualan, beban-beban operasi, beban keuangan(beban bunga) dan pajak.

c. Tahun 2015

$$
\begin{aligned}
\text { NPM } & =\frac{\text { Laba Bersih Setelah Pajak }}{\text { Pendapatan OPerasional }} \times 100 \% \\
& =\frac{R p 503.999}{R p 2.359 .768} \times 100 \% \\
& =2,135 \%
\end{aligned}
$$

Angka diatas memberikan arti bahwa setiap Rp 1 nilai penjualan, 2,135\% diantaranya (atau Rp 0,21357) akan menghasilkan laba setelah pajak. Perlu dipahami bahwa rasio ini merefleksikan: harga pokok penjualan, beban-beban operasi, beban keuangan(beban bunga) dan pajak.

Tabel 3.2

Perhitungan Net Profit Margin

Tahun 2013-2015

\begin{tabular}{cccc}
\hline Tahun & $\begin{array}{c}\text { Laba Bersih Setelah Pajak } \\
(1)\end{array}$ & $\begin{array}{c}\text { Pendapatan Operasional } \\
(2)\end{array}$ & $\begin{array}{c}\text { Net Profit Margin } \\
(1: 2 / x 100 \%)\end{array}$ \\
\hline 2013 & Rp 551.083 & Rp 2.104.492 & $2,618 \%$ \\
2014 & Rp 486.779 & Rp 2.009.656 & $2,422 \%$ \\
2015 & Rp 503.999 & Rp 2.359.768 & $2,135 \%$
\end{tabular}

Sumber: Data Hasil Olahan

Dari tabel diatas dapat dilihat laba bersih setelah pajak pada tahun 2013 sebanyak Rp. 551.083 dengan pendapatan operasional sebanyak Rp. 2.104 .492 dan pada tahun 2014 laba bersih setelah pajak Rp. 486,779 dengan pendapatan operasional Rp. 2.009.656 sedangkan pada tahun 2015 agak terjadi peningkatan dari tahun sebelumnya dengan laba bersih setelah pajak Rp. 503.999 dengan pendapatan operasional Rp. 2.359.768. namun angka ini masih mengalami penurunan dari tahun pertama yaitu tahun 2013. Dari tabel diatas dapat disimpulkan bahwa net profit margin bank PT BPR batang palangki mengalami penurunan laba, walaupun kemudian terjadi peningkatan tetapi tidak melampaui laba bersih pada tahun 2013. Sedangkan persentase 
net profit margin dari tahun 2013-2015 tidak mencapai rata-rata industri yaitu 3,92\% pertahun.

Tabel 3.3

Perkembangan Return On Asset

PT.BPR Batang Palangki

Tahun 2013-2015

\begin{tabular}{|c|c|c|c|}
\hline Keterangan & 2013 & 2014 & 2015 \\
\hline Laba Bersih Setelah Pajak & 551.083 & 486.779 & 503.999 \\
\hline Total Asset & 8.927 .456 & Rp 11.489.194 & 14.458 .035 \\
\hline
\end{tabular}

Sumber: BPR Batang Palangki, Data diolah

1. Return on Asset

a. Tahun 2013

$$
\begin{aligned}
\mathrm{ROA}=\frac{\text { Laba Bersih Setelah Pajak }}{\text { Total Aset }} \times 100 \% \\
=\frac{R p 551.083}{R p 8.927 .456} \times 100 \% \\
=6,17 \%
\end{aligned}
$$

ROA pada PT. BPR Batang Palangki nilainya belum tinggi, karena perusahaan tidak bisa menggunakan atau memanfaatkan aktiva yang dimilikinya didalam menghasilkan keuntungan setelah pajak.

b. Tahun 2014

$$
\begin{aligned}
& \mathrm{ROA}=\frac{\text { Laba Bersih Setelah Pajak }}{\text { Total Aset }} \times 100 \% \\
& =\frac{R p 486.779}{R p 11.489 .194} \times 100 \\
& =4,23 \%
\end{aligned}
$$

ROA pada PT. BPR Batang Palangki nilainya belum tinggi, karena perusahaan tidak bisa menggunakan atau memanfaatkan aktiva yang dimilikinya didalam menghasilkan keuntungan setelah pajak.

c. Tahun 2015

$$
\begin{gathered}
\mathrm{ROA}=\frac{\text { Laba Bersih Setelah Pajak }}{\text { Total Aset }} \times 100 \% \\
=\frac{R p 503.999}{R p 14.458 .035} \times 100 \% \\
=3,48 \%
\end{gathered}
$$

ROA pada PT. BPR Batang Palangki nilainya belum tinggi, karena perusahaan tidak bisa menggunakan atau memanfaatkan aktiva yang dimilikinya didalam menghasilkan keuntungan setelah pajak. 
Tabel 3.4

Perhitungan Return On Asset

Tahun 2013-2015

\begin{tabular}{cccc}
\hline Tahun & $\begin{array}{c}\text { Laba Bersih Setelah Pajak } \\
(1)\end{array}$ & $\begin{array}{c}\text { Total Asset } \\
(2)\end{array}$ & $\begin{array}{c}\text { Return On Asset } \\
(1: 2 / \mathrm{x} 100 \%)\end{array}$ \\
\hline 2013 & Rp 551.083 & Rp 8.927 .456 & $6,17 \%$ \\
2014 & Rp 486.779 & Rp 11.489 .194 & $4,23 \%$ \\
2015 & Rp 503.999 & Rp 14.458 .035 & $3,48 \%$ \\
\hline
\end{tabular}

Sumber: Data Hasil Olahan

Dari tabel perhitungan Return On Asset diatas dapat dilihat laba bersih setelah pajak pada tahun 2013 sebesar Rp. 551.083 dengan total asset Rp. 8.927.456 dan pada tahun 2014 dengan laba bersih setelah pajak yaitu Rp. 486.779 dan total asset Rp. 11.489.194 sedangkan pada tahun 2015 dengan laba bersih sebesar Rp. 503.999 dan total asset Rp. 14.458.035. jika dilihat dari persentase perhitungan Return On Asset dari tahun 2013-2015 tidak terjadi perubahan yang signifikan yaitu pada tahun 2013 dengan persentase $6,17 \%$ dan tahun 2014 dengan persentase 4,23 sedangkan pada tahun 2015 dengan persentase 3,48\%. Dari penjelasan diatas dapat disimpulkan bahwa BPR batang palangki dari tahun 2013-2015 belum dapat menghasilkan untung yang lebih maksimal dari asset yang dimiliki.

Tabel 3.5

Perkembangan Return On Equity

PT. BPR Batang Palangki Sijunjung

Tahun 2013-2015

\begin{tabular}{|c|c|c|c|c|c|}
\hline Keterangan & 2013 & 201 & & 201 & \\
\hline Laba Bersih Setelah Pajak & $\begin{array}{ll}\mathrm{Rp} & 551.083\end{array}$ & $\overline{\mathrm{Rp}}$ & 486.779 & $\mathrm{Rp}$ & 503.999 \\
\hline Modal Sendiri & $\mathrm{Rp} \quad 2.000 .000$ & $\mathrm{Rp}$ & 2.000 .000 & $\mathrm{Rp}$ & 2.000 .000 \\
\hline
\end{tabular}

Sumber:BPR Batang Palangki, Data Diolah

1. Return on Equity

a. Tahun 2013

$$
\begin{aligned}
\mathrm{ROA}=\frac{\text { Laba Bersih Setelah Pajak }}{\text { Modal Sendiri }} \times 100 \% \\
=\frac{R p 551.083}{R p 2.000 .000} \times 100 \% \\
=27,55 \%
\end{aligned}
$$

b. Tahun 2014

$$
\begin{gathered}
\mathrm{ROE}=\frac{\text { Laba Bersih Seteah Pajak }}{\text { Modal Sendiri }} \times 100 \% \\
=\frac{R p 486.779}{R p 2.000 .000} \times 100 \% \\
=24,3 \%
\end{gathered}
$$


c. Tahun 2015

$$
\begin{aligned}
R O E=\frac{\text { Laba Bersih Setelah Pajak }}{\text { Modal Sendiri }} \times 100 \% \\
=\frac{R p 503.999}{R p 2.000 .000} \times 100 \% \\
=25,11 \%
\end{aligned}
$$

Dari analisa diatas dapat disimpulkan bahwa nilai ROE tahun 2013 27,55\%, tahun 2014 24,3\% dan tahun 2015 25,11\%. Artinya kemampuan PT. BPR Batang Palangki tahun 2013 memperoleh keuntungan dari modal sendiri yang digunakan oleh bank tersebut, karena pada ROE tahun 2013 lebih efisien dari standar Bank Indonesia.

Tabel 3.6

Perhitungan Return On Equity

Tahun 2013-2015

\begin{tabular}{cccc}
\hline Tahun & $\begin{array}{c}\text { Laba Bersih Setelah Pajak } \\
(1)\end{array}$ & $\begin{array}{c}\text { Modal Sendiri } \\
(2)\end{array}$ & $\begin{array}{c}\text { Return On Equity } \\
(1: 2 / \mathrm{x} 100 \%)\end{array}$ \\
\hline 2013 & Rp 551.083 & Rp 2.000 .000 & $27,55 \%$ \\
2014 & Rp 486.779 & Rp 2.000 .000 & $24,3 \%$ \\
2015 & Rp 503.999 & Rp 2.000 .000 & $25,11 \%$ \\
\hline
\end{tabular}

Sumber: Data Hasil Olahan

Jika dilihat dari tabel perhitungan Return On Equity pada tahun 2013 dengan laba bersih setelah pajak yaitu Rp. 551.083 dengan modal sendiri sebesar Rp. 2000.000. dan pada tahun 2014 Rp. 486.779 dan modal sendiri sebesar Rp. 2000.000. sedangkan pada tahun 2015 dengan laba bersih setelah pajak Rp. 503,999 dan modal Rp. 2000.000. jika dilihat dari persentase perhitungan ROE maka dapat disimpulkan bahwa PT. BPR Batang Palangki mendapatkan laba yang maksimal dari modal yang dimiliki sendiri.

Setelah melakukan pembahasan untuk masing-masing kelompok rasio diatas, maka dapat disimpulkan rasio-rasio tersebut berdasarkan Rata-rata Industri sebagai berikut:

Tabel 3.7

Evaluasi Rasio Rata-rata Industri

PT. BPR Batang Palangki

Tahun 2013-2015

\begin{tabular}{cccccccc}
\hline Rasio & $\begin{array}{c}\text { Rata-rata } \\
\text { industri }\end{array}$ & $\begin{array}{c}\text { Tahun } \\
2013\end{array}$ & Evaluasi & $\begin{array}{c}\text { Tahun } \\
2014\end{array}$ & Evaluasi & $\begin{array}{c}\text { Tahun } \\
2015\end{array}$ & Evaluasi \\
\hline NPM & $3,92 \%$ & $2,618 \%$ & Buruk & $2,422 \%$ & Buruk & $2,135 \%$ & Buruk \\
ROA & $5,08 \%$ & $6,17 \%$ & Bagus & $4,23 \%$ & Buruk & $3,48 \%$ & Buruk \\
ROE & $8,32 \%$ & $27,55 \%$ & $\begin{array}{c}\text { Sangat } \\
\text { Bagus }\end{array}$ & $24,3 \%$ & $\begin{array}{c}\text { Sangat } \\
\text { Bagus }\end{array}$ & $25,11 \%$ & $\begin{array}{c}\text { Sangat } \\
\text { Bagus }\end{array}$ \\
\hline
\end{tabular}


Melalui tingkat antara rasio keuangan PT. BPR Batang Palangki Sijunjung, maka dapat diuraikan sebagai berikut:

1. Margin keuntungan PT. BPR Batang Palangki Sijunjung tahun 2013-2015 mengalami penurunan dari rata-rata industri.

2. Kemampuan PT. BPR Batang Palangki Sijunjung untuk menghasilkan laba dari total aktiva, belum mampu menghasikan tingkat keuntungan lebih dari rata-rata industri.

3. Jika dilihat dari sudut kemampuan PT.BPR Batang Palangki untuk menghasilkan laba dibanding modal sendiri yang berasal dari pemilik, perusahaan ini mampu menghasilkan tingkat keuntungan lebih bagus dibanding rata-rata industri.

\section{SIMPULAN}

Setelah melaksanakan analisa terhadap laporan keuangan pada PT. BPR Batang Palangki penulis dapat menarik kesimpulan

1. Secara umum efisiensi perusahaan mengalami penurunan pada tahun 2014 dan 2015.

2. Efektifitas manajemen dari tahun 2013 ke tahun 2014 dan tahun 2014 ke tahun 2015 menurun signifikan terutama pada NPM hingga dibawah standar BI.

3. Kemampuan perusahaan dalam menghasilkan laba bersih dari tahun ke tahun mengalami penurunan terlebih dari tahun2014 ke tahun 2015 hingga sampai dibawah standar BI.

4. Produktifitas penggunaan asset perusahaan sangat rendah, ini disebabkan margin laba karena rendahnya perputaran aktiva.

5. Kemampuan perusahaan dalam menghasilkan laba dari operasi pengembalian modal pada tahun 2013 sangat efisien karena nilai ROE pada tahun 2013 diatas standar BI.

\section{DAFTAR PUSTAKA}

Arifin, I. Z., \& Marlius, D. (2017). Analisis Kinerja Keuangan PT. Pegadaian Cabang Ulak Karang. https://doi.org/10.31227/osf.io/n2peu

Brigham, E.F. \& Houston, J.F. 2001. Manajemen Keuangan. Edisi Kedelapan. Erlangga. Jakarta

Hadayani, M., \& Marlius, D. (2017). Analisis Tingkat Kesehatan PT. BPR Batang Kapas. https://doi.org/10.31227/osf.io/bq48z

Harahap, Sofyan S. 2007. Analisis Kritis atas Laporan Keuangan. Edisi Kesatu. PT. Raja Grafindo Persada. Jakarta.

Horne, J.C.V. \& Wachowicz, J.M. 2005. Prinsip-Prinsip Manajemen Keuangan. Edisi 12 (diterjemahkan oleh Fitriasari, D \& Kwary, D.A ). Salemba Empat. Jakarta.

Kasmir, 2010. Analisa Laporan Keuangan.Edisi 1,2,3. Rajawali Pers. Jakarta 
Sawir, A., 2001. Analisa Kinerja Keuangan dan Perencanaan Keuangan Perusahaan, PT. Gramedia Pustaka Utama, Jakarta

Munawir, 2000. Analisa Laporan Keuangan, Edisi Empat, Liberty, Yogyakarta.

Kasmir, 2008. Analisis Laporan Keuangan, Rajawali Pers. Jakarta.

Rahmayeli, D. S., \& Marlius, D. (2017). Analisis Kinerja Keuangan Pada PT. Bank Perkreditan Rakyat (BPR) Batang Kapas Pesisir Selatan. https://doi.org/10.31227/osf.io/sz5db

Putri, Y. A., \& Marlius, D. (2018). Analisis Tingkat Kesehatan Bank Pada PT. Bank Perkreditan Rakyat (BPR) Jorong Kampuang Tangah Pariaman Cabang Padang. https://doi.org/10.31227/osf.io/r98pv

Shanjaya, A. R., \& Marlius, D. (2017). Peranan Laporan Keuangan Dalam Kebijaksanaan Pemberian Kredit Kepada Calon Nasabah Pada PT. BPR Batang Kapas. https://doi.org/10.31227/osf.io/uxmg6 